\title{
Pollination implications of the diverse diet of tropical nectar- feeding bats roosting in an urban cave
}

\author{
Voon-Ching Lim ${ }^{\text {Corresp.., }}{ }^{1,2}$, Rosli Ramli ${ }^{2}$, Subha Bhassu ${ }^{2,3}$, John-James Wilson ${ }^{4,5}$ \\ 1 Rimba, Kuala Lumpur, Malaysia \\ 2 Institute of Biological Sciences, Faculty of Science, University of Malaya, Kuala Lumpur, Malaysia \\ 3 Centre for Research in Biotechnology for Agriculture, University of Malaya, Kuala Lumpur, Malaysia \\ 4 School of Applied Sciences, Faculty of Computing, Engineering and Science, University of South Wales, Pontypridd, United Kingdom \\ 5 Department of Microbiology and Parasitology, Faculty of Medical Science, Naresuan University, Phitsanulok, Thailand \\ Corresponding Author: Voon-Ching Lim \\ Email address: voonchinglim@siswa.um.edu.my
}

Background. Intense landscaping often alters the plant composition in urban areas. Knowing which plant species that pollinators are visiting in urban areas is necessary for understanding how landscaping impacts biodiversity and associated ecosystem services. The cave nectar bat, Eonycteris spelaea, is an important pollinator for many plants and is often recorded in human-dominated habitats. Previous studies of the diet of $E$. spelaea relied on morphological identification of pollen grains found in faeces and on the body of bats and by necessity disregarded other forms of digested plant material present in the faeces (i.e., plant juice and remnants). The main objective of this study was to examine the diet of the nectarivorous bat, E. spelaea, roosting in an urban cave at Batu Caves, Peninsular Malaysia by identifying the plant material present in the faeces of bats using DNA metabarcoding.

Methods. Faeces were collected under the roost of $E$. spelaea once a week from December 2015 to March 2016. Plant DNA was extracted from the faeces, PCR amplified at ITS2 and rbcL regions and mass sequenced. The resultant plant OTU were searched against NCBI GenBank for identification.

Results. A total of 55 species of plants were detected from faeces of $E$. spelaea including Artocarpus heterophyllus, Duabanga grandiflora and Musa spp. which are likely to be important food resources for the cave nectar bat.

Discussion. Many native plant species that had not been reported in previous dietary studies of $E$. spelaea were detected in this study including Bauhinia strychnoidea and Urophyllum leucophlaeum, suggesting that $E$. spelaea remains a crucial pollinator for these plants even in highly disturbed habitats. The detection of many introduced plant species in the bat faeces indicates that $E$. spelaea are exploiting them, particularly Xanthostemon chrysanthus, as food resources in urban area. Commercial food crops were detected from all of the faecal samples, suggesting that $E$. spelaea feed predominantly on the crops particularly jackfruit and banana and play a significant role in pollination of economically important plants. Ferns and figs were also detected in the faeces of $E$. spelaea suggesting future research avenues to determine whether the "specialised nectarivorous" E. spelaea feed opportunistically on other parts of plants. 
1 Pollination implications of the diverse diet of tropical nectar-feeding bats roosting in an

2 urban cave

3 Voon-Ching Lim ${ }^{1,2}$, Rosli Ramli², Subha Bhassu ${ }^{2,3}$ and John-James Wilson ${ }^{4,5}$

$4 \quad{ }^{1}$ Rimba, Kuala Lumpur, Malaysia

5 2Institute of Biological Sciences, Faculty of Science, University of Malaya, 50603 Kuala

6 Lumpur, Malaysia

$7{ }^{3}$ Centre for Research in Biotechnology for Agriculture, University of Malaya, 50603 Kuala

8 Lumpur, Malaysia

$9{ }^{4}$ School of Applied Sciences, Faculty of Computing, Engineering and Science, University of

10 South Wales, Pontypridd, CF37 4DB, United Kingdom

$11{ }^{5}$ Department of Microbiology and Parasitology, Faculty of Medical Science, Naresuan

12 University, Phitsanulok 65000, Thailand

14 Corresponding Author:

15 Voon-Ching $\operatorname{Lim}^{1}$

16 Email address: voonchinglim@siswa.um.edu.my, voonchinglim@,gmail.com 


\section{ABSTRACT}

19 Background. Intense landscaping often alters the plant composition in urban areas. Knowing

20 which plant species that pollinators are visiting in urban areas is necessary for understanding

21 how landscaping impacts biodiversity and associated ecosystem services. The cave nectar bat,

22 Eonycteris spelaea, is an important pollinator for many plants and is often recorded in human-

23 dominated habitats. Previous studies of the diet of E. spelaea relied on morphological

24 identification of pollen grains found in faeces and on the body of bats and by necessity

25 disregarded other forms of digested plant material present in the faeces (i.e., plant juice and

26 remnants). The main objective of this study was to examine the diet of the nectarivorous bat, $E$.

27 spelaea, roosting in an urban cave at Batu Caves, Peninsular Malaysia by identifying the plant

28 material present in the faeces of bats using DNA metabarcoding.

29 Methods. Faeces were collected under the roost of E. spelaea once a week from December 2015

30 to March 2016. Plant DNA was extracted from the faeces, PCR amplified at ITS2 and $r b c L$

31 regions and mass sequenced. The resultant plant OTU were searched against NCBI GenBank for 32 identification.

33 Results. A total of 55 species of plants were detected from faeces of E. spelaea including

34 Artocarpus heterophyllus, Duabanga grandiflora and Musa spp. which are likely to be important

35 food resources for the cave nectar bat.

36 Discussion. Many native plant species that had not been reported in previous dietary studies of

37 E. spelaea were detected in this study including Bauhinia strychnoidea and Urophyllum

38 leucophlaeum, suggesting that E. spelaea remains a crucial pollinator for these plants even in

39 highly disturbed habitats. The detection of many introduced plant species in the bat faeces 
40 indicates that E. spelaea are exploiting them, particularly Xanthostemon chrysanthus, as food

41 resources in urban area. Commercial food crops were detected from all of the faecal samples,

42 suggesting that E. spelaea feed predominantly on the crops particularly jackfruit and banana and

43 play a significant role in pollination of economically important plants. Ferns and figs were also

44 detected in the faeces of E. spelaea suggesting future research avenues to determine whether the

45 “specialised nectarivorous" E. spelaea feed opportunistically on other parts of plants.

46 


\section{INTRODUCTION}

48 Urban land cover in Peninsular Malaysia expanded from $4,644.3 \mathrm{~km}^{2}$ in year 2000 to $5,364.4$

$49 \mathrm{~km}^{2}$ in year 2010 with an average annual increase of $1.5 \%$ (Schneider et al., 2015). Intense

50 landscaping often increases the species richness and homogeneity of plants in these urban areas

51 (Grimm et al., 2008; Kowarik, 2011). These plants support diverse assemblages of birds and bats

52 (Corlett, 2005; Aida et al., 2016), which in turn provide seed dispersal and pollination services,

53 and consequently aid in maintaining urban green spaces (Tan et al., 2000; Corlett, 2005;

54 Sheherazade et al., 2017). However, the preference for planting non-native species in parks and

55 household gardens for urban beautification and food may create competition for pollination

56 services which could affect the reproductive success and survival of native plants (Faeth et al.,

57 2005). Knowing which plants pollinators are visiting in urban areas is essential for assessing how

58 planting schemes will affect biodiversity and associated ecosystem services.

59 The cave nectar bat, Eonycteris spelaea (family: Pteropodidae), is generally categorised as

60 specialised nectarivorous bat (Fleming et al., 2009; Stewart \& Dudash, 2017) that feeds on

61 nectar and pollen, and consequently provides pollination services (Srithongchuay et al., 2008;

62 Bumrungsri et al., 2009; Acharya et al., 2015a; Nor Zalipah et al., 2016). E. spelaea is one of

63 three nectarivorous bats present in Peninsular Malaysia and is often recorded in urban and

64 agricultural areas (Lim et al., 2017a). The capability of E. spelaea to travel long distances for

65 food and visit night-blooming plants with high frequency likely contributes to an important role

66 as a pollinator (Start \& Marshall 1976; Stewart \& Dudash, 2017).

67 The diet of E. spelaea in Southeast Asia was previously assessed through morphological

68 identification of pollen grains (found in faeces and on the body of bats) examined

69 microscopically. Start and Marshall (1976) observed 31 distinct types of pollen in faeces of $E$. 
70 spelaea collected under two roosts at Batu Caves and Gua Sanding in Peninsular Malaysia but

71 could only identify the pollen grains of 17 plant species. Bumrungsri et al. (2013) collected

72 eleven types of pollen from captured individuals of E. spelaea at Khao Kao Cave in Thailand but

73 could only identify the pollen grains of four plant species. Similarly, Thavry et al. (2017)

74 recorded thirteen types of pollen in faeces of a roosting colony at Bat Khteas Cave in Cambodia

75 but could only identify the pollen grains of four plant species. The lack of distinctive

76 morphological characters on pollen grains (Bell et al., 2016) and lack of reference specimens for

77 comparison (Aziz et al., 2017a) likely account for the difficulties in identification of plant

78 species. Furthermore, these studies prioritised pollen grains (solid plant material which are

physically identifiable in faeces) and by necessity disregarded other types of plant material

80 defecated by the bats (i.e., nectar and leaf fragments). As E. spelaea feeds mainly on nectar and

81 pollen (Fleming et al., 2009; Stewart \& Dudash, 2017), and possibly on fruits and leaves (Start \&

82 Marshall, 1976; Bumrungsri et al., 2013), it is necessary to identify all the plant material present

83 in the faeces in order to have a complete picture of the ecological role of the cave nectar bat.

84 DNA barcoding (Hebert et al., 2003) can aid in identification of digested plant material in faeces

85 of bats (Hayward, 2013) without requiring the high level of taxonomic expertise necessary for

86 microscopic identification of pollen grains (Pompanon et al., 2012). Plant DNA can be extracted

87 from faeces, PCR amplified with taxon-specific universal PCR primers (e.g., rbcL and ITS2

88 [CBOL, 2009; Chen et al., 2010]), and sequenced to recover short DNA sequences which can be

89 matched to taxonomically verified sequences for species identification (Pompanon et al., 2012).

90 Recent advances in high-throughput sequencing platforms have introduced DNA metabarcoding

91 which involves simultaneous DNA sequencing of multiple templates in complex samples (e.g.,

92 faeces) and allows detection of multiple species in a single sample (Pompanon et al., 2012; 
93 Brandon-Mong et al. 2015). DNA metabarcoding has been widely used to identify the diet of

94 honey bees (de Vere et al., 2017), omnivorous brown bears (De Barba et al., 2014), large

95 herbivores (Kartzinel et al., 2015), and insectivorous (Clare et al., 2014) and frugi-nectarivorous

96 bats (Aziz et al., 2017a).

97 The aim of this study was to examine the diet of E. spelaea roosting in an urban cave in

98 Peninsular Malaysia by using DNA metabarcoding to identify the digested plant material in bat

99 faeces. Specifically, we asked whether E. spelaea (i) feeds primarily on native plants and still

100 serves as their crucial pollinator in an urban area, or (ii) exploits introduced plant species (which

101 are commonly planted for food and urban beautification) as food resources, potentially

102 pollinating them and impacting the reproductive success of native plants.

\section{MATERIALS AND METHODS}

104 Ethics

105 Faecal collection was conducted at Dark Cave, Batu Caves with authorization from the

106 Department of Wildlife and National Parks, Peninsular Malaysia (Ref: JPHL\&TN(IP)100-

107 34/1.24 Jld. 4(34)), the Malaysian Nature Society and Majlis Perbandaran Selayang (Ref:

108 Bil(35)dlm.MPS 3/3-117/153 JL) using a protocol approved by the Institutional Animal Care and

109 Use Committee, University of Malaya (Ref: ISB/10/06/2016/LVC (R)).

110 Study site and bat species

111 Batu Caves constitute an extensive karst cave system developed within an isolated $329 \mathrm{~m}$ high

112 limestone massif located in Gombak District, part of the Klang Valley conurbation in Selangor

113 state adjacent to Kuala Lumpur Federal Territory (Moseley et al., 2012; Grismer et al., 2014).

114 Batu Caves is surrounded by industrial parks and residential areas (Grismer et al., 2014) and 
115 includes a Hindu temple that has become a major tourist attraction (Kasim, 2011). The cave

116 complex includes the Dark Cave, a protected cavern with $>2000 \mathrm{~m}$ of passages (Price, 2002)

117 managed by the Cave Management Group under the Malaysian Nature Society

118 (http://www.darkcavemalaysia.com/). Dark Cave is an ecologically diverse karst cave system

119 which supports a large number of animals (Moseley, 2009; Moseley et al., 2012) including a

120 colony of E. spelaea. Start \& Marshall (1976) estimated that the colony comprised $>10,000$

121 individuals whereas Beck and Lim (1972) and Gould (1988) estimated $>4000$ individuals. For

122 this study, faecal samples were collected under the E. spelaea roost at Dark Cave (Figure 1).

123 Faecal collection

124 Approximately $10 \mathrm{ml}$ of fresh faecal samples were collected non-invasively under the roost of $E$.

125 spelaea once every week from 31 December 2015 to 4 March 2016 (i.e., 10 days over 10 weeks).

126 Overall, a total of $\sim 100 \mathrm{ml}$ of fresh faecal material was collected and used for the study. As the

127 Cave Management Group cleans the floor below the roost daily to prevent the accumulation of

128 bat faeces (which is unappealing to tourists), faeces below the roost were assumed to be

129 deposited the previous night. The faeces were kept in $1.5 \mathrm{~mL}$ tubes filled with $99.8 \%$ ethanol and

130 stored at $-20^{\circ} \mathrm{C}$ prior to analysis (following Lim et al., 2017b).

131 Preparation of faecal samples

132 The faeces were centrifuged to form pellets and the supernatant were discarded. The pellets were

133 incubated at $56^{\circ} \mathrm{C}$ for 2 hours to evaporate moisture (i.e., ethanol), pooled according to collection

134 week and homogenised using a TissueLyser II (Qiagen, Germany) with $3 \mathrm{~mm}$ tungsten carbide

135 beads (Qiagen, Germany) for 4 minutes at 30 1/s.

136 Plant DNA extraction, PCR amplification, clean-up and sequencing 
137 DNA extraction was performed twice using the QIAamp DNA stool mini kit (QIAGEN,

138 Germany) following the manufacturer's protocol which resulted in two DNA replicates for each

139 weekly sample. The purity and concentration of the DNA was examined with NanoDrop 2000c

140 UV-Vis Spectrophotometer (Thermo Fisher Scientific). DNA extracts with a purity range from

1411.8 to 1.9 and concentrations $\geq 50 \mathrm{ng} / \mu \mathrm{l}$ were used for PCR amplification.

142 Two DNA barcode markers were selected for this study: $r b c L$ due to its relative universality (i.e.,

143 universal primers; CBOL, 2009) and ITS2 due its higher taxonomic resolution (Chen et al.,

144 2010). Both markers have a large number of taxonomically verified DNA reference sequences

145 available in NCBI GenBank (http://www.ncbi.nlm.nih.gov/) $(r b c l=155,634 ;$ ITS2= 243,155;

146 Bell et al., 2016) and have been used successfully to examine the diet of rolled-leaf beetles in a

147 tropical rainforest in Costa Rica (García-Robledo et al., 2013) and the plant sources of honey

148 (Prosser \& Hebert, 2017).

149 Fragments of $r b c L$ and ITS2 were amplified using universal primers with Illumina adaptors

150 (Supplementary Information 1). Five PCR amplifications were performed for each DNA extract

151 replicate together with one positive (Musa sp.) and one negative $\left(\mathrm{ddH}_{2} 0\right)$ control. Each PCR

152 amplification was performed in a total volume of $25 \mu \mathrm{L}$ consisting of $12.5 \mu \mathrm{L}$ EconoTaq PLUS

153 GREEN 2X Master Mix (Lucigen, USA), $0.25 \mu \mathrm{L}$ of each forward and reverse primer $(100 \mu \mathrm{M})$,

$1547-8 \mu \mathrm{L}$ of $\mathrm{ddH}_{2} \mathrm{O}$, and $4-5 \mu \mathrm{L}$ of DNA. The thermocycling profile for $r b c L$ was: initial

155 denaturation at $95{ }^{\circ} \mathrm{C}$ for 2 minutes, denaturation, annealing and extension at $95{ }^{\circ} \mathrm{C}$ for 30

156 seconds, $55^{\circ} \mathrm{C}$ for 30 seconds, $72{ }^{\circ} \mathrm{C}$ for 10 seconds $\left(35\right.$ cycles), and a final extension at $72{ }^{\circ} \mathrm{C}$

157 for 6 minutes. The thermocycling profile for ITS2 was: initial denaturation at $94{ }^{\circ} \mathrm{C}$ for 2

158 minutes, denaturation, annealing and extension of $94{ }^{\circ} \mathrm{C}$ at 30 seconds, $55^{\circ} \mathrm{C}$ at 30 seconds, 72

$159{ }^{\circ} \mathrm{C}$ at 20 seconds ( 35 cycles), and a final extension at $72^{\circ} \mathrm{C}$ for 10 minutes. 
160 PCR products were checked on 2\% agarose gels and extracted and purified using a NucleoSpin

161 Gel and PCR Clean-up kit (Macherey-Nagel, Germany) following the manufacturer's

162 instructions. The purified products were assessed with a NanoDrop 2000c UV-Vis

163 Spectrophotometer (Thermo Fisher Scientific). Products with purity ranging from 1.8 to 1.9 and

164 concentration $\geq 50 \mathrm{ng} / \mu \mathrm{l}$ were used for a second round of PCR to generate amplicons containing

165 dual-index multiplex identifier (MID) tags and sequencing on an Illumina Miseq Sequencer

166 (Illumina, USA) with $2 \times 300$ bp paired-end read setting.

167 Paired-end reads were sorted into datasets (i.e., weeks) by MID and merged (for ITS2). RbcL

168 reads could not be merged due to the lack of overlapping sequence between paired-end reads.

169 Therefore, $r b c L$ reads containing only the forward primer were used in subsequent steps as these

170 sets of reads were longer and more abundant.

171 Filtering pipeline

172 Using the Galaxy web server (https://usegalaxy.org/, Giardine et al., 2005), files were converted

173 to Illumina1.8+ format using "FASTQ Groomer" (Blankenberg et al., 2010). Primers were

174 removed using "Clip" (http://hannonlab.cshl.edu/fastx toolkit).. Short (rbcL $<100$ bp; ITS2 $<320$

175 bp) and low quality $(\mathrm{QV}<20)$ reads were discarded using "Filter FASTQ" (Blankenberg et al.,

176 2010). Remaining reads were de-replicated with $100 \%$ identity using "VSearch dereplication"

177 (Rognes et al., 2015). Duplicates and possible chimeras were then removed using "cd-hit-dup"

178 (Fu et al., 2012). Remaining reads were clustered into operational taxonomic units (OTU) with

179 98\% identity using "VSearch clustering" (Rognes et al., 2015). 
181 OTU were BLAST-ed against NCBI GenBank (https://blast.ncbi.nlm.nih.gov/Blast.cgi; Boratyn

182 et al., 2013) with the following Megablast parameters: Identity $=100 \%$, Minimum score $=300$, and

183 Maximum Expected Value $=0.01$. Taxonomic names were assigned to OTU using the following

184 criteria: (i) when the OTU matched to records from one species only, the species name was

185 assigned; (ii) when the OTU matched to records from multiple species from one genus only, the

186 genus name was assigned; (iii) when the OTU matched to records from multiple genera

187 belonging to one family only, the family name was assigned.

188 Taxonomic names were checked against Corner (1997) and Boo et al. (2014) for the local uses

189 of the species (e.g., food, medicinal and aesthetic), and against the Catalogue of Life

190 (www.catalogueoflife.org) for the status of the species as native or introduced. To assess whether

191 the species potentially provide stable (i.e., flower throughout the year) or alternative (i.e., flower

192 seasonally) food resources to the cave nectar bats, the taxonomic names were checked against

193 local literature for information regarding the flowering phenology: Flora of the Malay Peninsula

194 (Ridley, 1922 - 1925), Tree flora of Malaya: a manual for foresters (Whitmore, 1972 - 1989),

195 Wayside trees of Malaya (Corner, 1997), Flora of Peninsular Malaysia (Kiew et al., 2010 -

196 2015; Parris et al., 2010 - 2013), and Plants in Tropical Cities (Boo et al., 2014). See

197 Supplementary Information 2 for further details on the flowering phenology of each taxonomic 198 names.

199 Species richness and sampling completeness ratio

200 All analyses were performed using R version 3.3.1. (R Core Team, 2017). The detection of plant

201 species in faecal samples of E. spelaea was recorded as absent or present following Prosser and

202 Hebert (2017). Currently, DNA metabarcoding cannot be considered quantitative due to

203 biological (e.g. varying copy numbers of plastid and nuclear DNA in pollen among and within 
204 species; Bell et al., 2016) and methodological (e.g. PCR amplification bias caused by universal

205 primers; Prosser \& Hebert, 2017) factors. The species richness and the sampling completeness

206 ratio were estimated using the SpadeR package (Chao \& Shen, 2010). Chao2 is more suitable for

207 the incidence-type data collected in this study as it estimates the species richness based on the

208 incidence of each species (i.e., presence or absence) recorded in each sampling unit (Chao \&

209 Chiu, 2016). Several Chao2 models were used to assess consistency of estimates provided by

210 each model. A homogeneous model was also included under the assumption that all plant species

211 have the same detection probabilities, but usually severely underestimates the true species

212 richness if heterogeneity exists (Chao \& Chiu, 2016). Rarefaction and extrapolation sampling

213 curves of estimated species richness and the sampling completeness ratio were created using the

214 iNEXT package (Hsieh et al., 2016) with Chao2 and a 95\% confidence interval (R scripts are

215 available as Supplementary Information 3).

216 Relative detection rate of each plant species in faeces of cave nectar bats

217 To apply a consistent terminology, if a plant species was detected in (i) $\geq 8$ of the 10 weekly

218 samples, it was considered "frequently" detected, (ii) $>3$ but $<8$ of the 10 weekly samples, it was

219 considered "moderately" detected, and (iii) $\leq 3$ of the weekly samples, it was considered

220 "infrequently" detected.

\section{RESULTS}

222 A total of 47 OTU ( $\sim 320 \mathrm{bp})$ were detected using ITS2 primers and 13 OTU ( $200 \mathrm{bp})$ were

223 detected using $r b c L$ primers. $R b c L$ OTU which were assigned with a genus and/or family name

224 that was also assigned to an ITS2 OTU were discarded as likely duplicates. This resulted in 55

225 OTU (ITS2 $=47, r b c L=8)$, of which 37 OTU were assigned a species name (ITS2=36, $r b c L=1)$, 
226 fourteen were assigned a genus name $(I T S 2=11, r b c L=3)$ and the remaining four were assigned a

227 family name $(r b c L=4)$ (Figure 2; Supplementary Information 2). An average of 18 OTU were

228 detected each week $(\mathrm{sd}=5.103, \min =12, \max =30)$.

229 The plant species richness in faecal samples of E. spelaea estimated by different models were

230 within the range of 65.260 to 68.961 (Table 1). The sampling completeness ratio was estimated

231 to be 0.912 (Figure 3). Both asymptotic (species richness estimation) and non-asymptotic

232 analyses (rarefaction/extrapolation) suggested that a longer sampling period and larger faecal

233 sample size would detect more plant species in the diet of E. spelaea (Figure 3).

234 Of the 55 plant species, 24 were native (ITS2 OTU=23; $r b c L$ OTU=1) while 16 were introduced

235 to Peninsular Malaysia (ITS2 OTU=16) (Table 2). The status of the remaining 15 plant species is

236 unknown (ITS2 OTU=8; rbcL OTU=7) as we could not assign them to a species name. We

237 detected 49 plant species which have not been reported by previous dietary studies of E. spelaea

238 conducted during the same sampling months (i.e., December to March) (Table 2).

239 Two native plant species, Duabanga grandiflora and Musa balbisiana, and an introduced

240 species, Artocarpus heterophyllus, were detected from all ten faecal samples (i.e. every week)

241 and were flowering during the sampling period (Figure 2; Table 2). The native Musa acuminata

242 and the introduced Ceiba pentandra were detected in nine faecal samples, and were flowering

243 during the sampling period. The native Urophyllum leucophlaeum and a fern, Dicranopteris sp.,

244 were detected in eight faecal samples.

245 DISCUSSION

246 By using DNA metabarcoding to identify the plant species present in faeces of E. spelaea

247 collected over ten weeks, we detected 55 plant species, many of which had not been reported in 
248 previous studies of the diet of E. spelaea (including studies conducted during the same time of 249 year; Table 2). In this study, most of the detected plants could be assigned to a species name. For 250 example, the two OTU belonging to the economically important genus Artocarpus could be 251 identified as Artocarpus elasticus and A. heterophyllus, whereas Start and Marshall (1976) could 252 only identify pollen grains to the genus Artocarpus but could not assign to a species name. In 253 addition, the failure of previous studies (which examined the morphology of pollen grains) to 254 detect pollen grains of species recorded in this study may be due to degradation of the pollen 255 grains in the bats' gastrointestinal tract (Herrera \& Martinez del Rio, 1998). Therefore, it is 256 difficult to conclude if the detection of these species in this study is due to the changing 257 landscape or a result of the better detection capability of DNA metabarcoding.

258 In contrast, this study failed to detect several plant species that were previously recorded in the 259 diet of E. spelaea (Table 2; Supplementary Information 4). This may be due to the plant DNA 260 barcoding primers used in this study which could be biased towards the detection of particular 261 plant families (García-Robledo et al., 2013; Prosser \& Hebert, 2017). Furthermore, using 262 BLAST (against NCBI GenBank) for OTU identification is limited to plant species which have 263 already been sequenced and submitted to the database (Bell et al., 2016; Bell et al., 2017).

264 Consequently, this study may have failed to detect some of the previously reported diet species 265 that are not currently in NCBI GenBank (e.g., Bombax anceps and Syzygium malaccensis).

266 The short sampling period of this study (31 December 2015 - 4 March 2016) may also account 267 for the failure to detect certain plant species. Although the relatively high sampling completeness 268 ratio and estimated plant species richness support the adequacy of the sampling effort for this 269 study, both estimates only apply for the particular sampling period (when only certain plant 270 species were flowering). As floral community changes over time (Boulter et al., 2006; Delaney 
271 et al., 2015), especially in Peninsular Malaysia where many species flower at irregular intervals

272 (Appanah, 1993; Chen et al., 2017), a longer sampling period and larger faecal sample size will

273 likely reveal more plant species in the diet of E. spelaea.

274 The native plant species, Duabanga grandiflora and Musa spp. were frequently detected during

275 our study and, considering these species flower year-round, likely represent a stable food

276 resource for cave nectar bats throughout the year. Two other native plant species: Urophyllum

277 leucophlaeum, which has been recorded in hill and montane forests in Peninsular Malaysia

278 (Wong, 1989), and Bauhinia strychnoidea, a calciphile plant which has been recorded from Batu

279 Caves (Ridley, 1922), were frequently and infrequently detected in the bat faeces. Little is

280 known about the flowering phenology and pollination ecology of these plants. The infrequent

281 detection of a mangrove plant, Sonneratia caseolaris, which flowers year-round, suggests that

282 the species is not an important food resource for these particular cave nectar bats, yet indicates

283 that some bats likely travelled $\sim 40 \mathrm{~km}$ from Batu Caves to the nearest mangrove forest at Kuala

284 Selangor. This is congruent with the finding of Start (1974) who observed that individuals of $E$.

285 spelaea roosting at Batu Caves travelled $38 \mathrm{~km}$ to Rantau Panjang to feed on Sonneratia alba.

286 Interestingly, Acharya et al. (2015b) estimated the foraging range for E. spelaea in southern

287 Thailand to be $17.9 \mathrm{~km}$ only, though this could be due to the fact that the cave roosts in that

288 particular study were located in agricultural areas where the cultivated fruit orchards nearby

289 provided an easy source of food. In contrast, E. spelaea in Batu Caves appears to travel long

290 distances from the roost to different habitats (i.e., mangrove, limestone and montane forests)

291 where it feeds and consequently may promote genetic diversity among plant populations by

292 dispersing pollen (see review by Fleming et al., 2009). Radio-tracking the cave nectar bats at

293 Batu Caves remains a highly desirable approach to determine their foraging distances, and assess 
294 whether the long-distance travelling behaviour (i) is sex-specific where female tend to forage

295 further while male tend to forage closer to roost as observed in E. spelaea in Thailand

296 (Bumrungsri et al., 2013) and Pteropus rufus in Madagascar (Oleksy et al., 2015), and (ii)

297 whether it is a strategy to reduce extreme competition for food which may be a consequence of

298 the gregarious roosting behaviour of E. spelaea as recognised for Leptonycteris curasoae in

299 Mexico (Horner et al., 1989). Together these findings support the view that E. spelaea remain a

300 crucial pollinator of native plants in highly disturbed habitats.

301 We detected many plant species which were introduced to Peninsular Malaysia and have since

302 naturalised in the region including Artocarpus heterophyllus and Ceiba pentandra which are

303 commonly planted in human settlements for fruits (Corner, 1997) and were flowering during the

304 sampling period. The high detection rate of these introduced plants in the bat faeces suggests that

305 these plants may be important food resource for the cave nectar bats in human-dominated

306 habitats. On the other hand, the moderate and infrequent detection rate of other introduced plant

307 species which are often planted for urban beautification and shade (e.g., Chrysanthemum sp.,

308 Leucaena leucocephala and Xanthostemon chrysanthus) suggests that these plants may be

309 supplement food resources for the bats (Corlett, 2005; Nakamoto et al., 2007). However,

310 consumption and potential pollination of these introduced plants by cave nectar bats may have an

311 adverse impact on the reproductive success of native plants (Morales \& Traveset 2009) and on

312 other dependant urban wildlife (Corlett, 2005; Grimm et al., 2008). Therefore, the status of a

313 plant species should be considered carefully prior to gardening and landscaping activities.

314 Planting native plants instead of introduced plants could help to promote the consumption and

315 hence pollination of native plants by the cave nectar bats, which consequently could maintain

316 healthy ecosystems in urban areas. 
317 Many of the plant species detected in this study are grown as commercial food crops including

318 jackfruit (Artocarpus heterophyllus), banana (Musa spp.), water apple (Syzygium samarangense),

319 mango (Mangifera indica) and papaya (Carica papaya); most of these plants were likely to be

320 flowering during the sampling period. One of the commercial food crops which was frequently

321 detected and flowers seasonally is jackfruit; a fruit with an estimated production value of RM 55

322 million for year 2011 (Abd-Aziz et al., 2016). The previous study in Peninsular Malaysia also

323 reported pollen grains of genus Artocarpus in faeces of E. spelaea (Start \& Marshall, 1976).

324 Altogether it is likely that E. spelaea play an important role in pollination of this economically

325 important plant species.

326 Plant species which are pollinated and/or dispersed by wind and/or insects were detected in the

327 bat faeces including ferns (e.g., Adiantum sp. and Pleocnemia sp.), weeds (e.g., Bidens pilosa,

328 Cuminum cyminum, Cyathula prostrata, Oldenlandia corymbosa), figs (Ficus spp.) and

329 Artocarpus elasticus (Corner, 1997; Boo et al., 2014). The infrequent detection of these plant

330 species suggest they form a relatively minor part of the cave nectar bat's diet or were

331 unintentionally consumed. It could also be likely that the spores and pollen grains of these plant

332 species may have adhered to the fur of the cave nectar bats when they were foraging (Corbet et

$333 a l ., 1982$ ) and consequently were ingested when they groomed themselves later (Fleming et al.,

334 2009). Another potential explanation (though unlikely given our protocol) is that the spores and

335 pollen grains of these plant species may have been unintentionally collected when sampling the

336 bat faeces directly from the cave floor.

337 One limitation of DNA metabarcoding is the inability to identify which part of the plant is being

338 consumed by the bats. Previous studies have observed remains of fruits and leaves in faeces and

339 under the day roosts of E. spelaea, and consequently suggested that fruits and leaves may form a 
340 part of the cave nectar bat's diet (Start \& Marshall, 1976; Bumrungsri et al., 2013). Similarly, we

341 detected ferns and figs (which were either not flowering during the sampling period or have

342 unknown flowering phenology) in the faeces of E. spealea but could not determine whether the

343 bats were feeding on the fronds and fruits or ingesting the spores and pollen grains inadvertently.

344 It is possible that E. spelaea chew the fronds and fruits, ingest the juice (and possibly fragments

345 of the fronds and fruits), and spit out the fibres later; a feeding behaviour which is common in

346 pteropodid bats including Cynopterus brachyotis (Phua \& Corlett, 1989; Tan et al., 1998) and

347 Pteropus spp. (e.g., Nakamoto et al., 2007; Scanlon et al., 2014; Win \& Mya, 2015; Aziz et al.,

348 2017a). The ability of pteropodid bats to eat fronds and disperse the spores of the bird-nest fern

349 (Asplenium setoi) has also been demonstrated in a feeding experiment with P. pselaphon, an

350 endemic to islands in Japan (Sugita et al., 2013). Whether E. spelaea is specialised nectarivore or

351 feeds opportunistically on other parts of plants remains to be determined. Observations of $E$.

352 spelaea's feeding behaviour, possibly using camera traps as demonstrated in a study of the

353 locally endangered $P$. hypomelanus (Aziz et al., 2017b), is a promising further avenue of

354 research to determine (i) which part of the plants are being consumed by the bats and (ii) the

355 interactions between the bats and plants (e.g., bats dispersing spores and seeds). Nevertheless,

356 the use DNA metabarcoding in this study has provided important baseline data for future

357 research into the diet of tropical nectarivorous bats.

\section{ACKNOWLEDGEMENTS}

359 We thank the Cave Management Group (http://www.darkcavemalaysia.com/) for allowing us to

360 collect samples at Dark Cave Conservation Site. We also thank Tan Kai Ren for providing

361 assistance during fieldwork, Sugumaran Manickam and Yong Kien Thai from the Herbarium,

362 University of Malaya (http://rimba.um.edu.my/) for their advice on plant identification and 
363 Sheema Aziz from Rimba (rimbaresearch.org) for providing helpful literature and advice on data

364 analyses. We are grateful to Ana Rainho, Alyssa Stewart, Maria Pereira and an anonymous

365 reviewer for their comments on earlier version of this manuscript. This project was presented at

366 the XIX International Botanical Congress in July 2017 and $22^{\text {nd }}$ Biological Sciences Graduate

367 Congress in December 2017.

368 DATA AVAILABILITY

369 Raw sequence data related to this study were deposited in Sequence Read Archive (SRA) at

370 NCBI GenBank under accessions SAMN07956186 to SAMN07956205.

\section{REFERENCES}

372 Abd-Aziz, N. B., Abd-Rahman, M., \& Razali, M. Z. (2016). Fruit morphology description of seven jackfruit clones from farmers collection. In Regional Conference on Science, Technology and Social Sciences (RCSTSS 2014): Science and Technology (pp. 549-556).

Aida, N., Sasidhran, S., Kamarudin, N., Aziz, N., Puan, C. L., \& Azhar, B. (2016). Woody trees, green space and park size improve avian biodiversity in urban landscapes of Peninsular Malaysia. Ecological Indicators, 69, 176-183.

Acharya, P.R., Racey, P.A., Sotthibandhu, S. \& Bumrungsri, S.(2015a). Feeding behaviour of the dawn bat (Eonycteris spelaea) promotes cross-pollination of economically important plants in Southeast Asia. Journal of Pollination Ecology 15(7): 44-50. 
382 Acharya, P. R., Racey, P. A., Sotthibandhu, S., \& Bumrungsri, S. (2015b). Home-range and 383 foraging areas of the dawn bat Eonycteris spelaea in agricultural areas of Thailand. Acta 384 Chiropterologica, 17(2), 307-319.

385 Appanah, S. (1993). Mass flowering of dipterocarp forests in the aseasonal tropics. Journal of $386 \quad$ Biosciences, 18(4), 457-474.

387 Aziz, S. A., Clements, G. R., Peng, L. Y., Campos-Arceiz, A., McConkey, K. R., Forget, P. M., 388 \& Gan, H. M. (2017a). Elucidating the diet of the island flying fox (Pteropus hypomelanus) in Peninsular Malaysia through Illumina Next-Generation Sequencing. PeerJ, 5, e3176.

Aziz, S. A., Clements, G. R., McConkey, K. R., Sritongchuay, T., Pathil, S., Yazid, A., ... \& Bumrungsri, S. (2017b). Pollination by the locally endangered island flying fox (Pteropus hypomelanus) enhances fruit production of the economically important durian (Durio

Beck, A. J., \& Lim, B. L. (1972). Reproductive biology of Eonycteris spelaea, Dobson (Megachiroptera) in West Malaysia. Acta Tropica, 30(4), 251-260. (2016). Pollen DNA barcoding: current applications and future prospects. Genome, 59(9), 629-640.

Bell, K. L., Loeffler, V. M., \& Brosi, B. J. (2017). An rbcL reference library to aid in the 401 identification of plant species mixtures by DNA metabarcoding. Applications in Plant Sciences, 5(3), 1600110. 
403 Blankenberg, D., Kuster, G. V., Coraor, N., Ananda, G., Lazarus, R., Mangan, M., ... \& Taylor, 404 J. (2010). Galaxy: a web-based genome analysis tool for experimentalists. Current 405 protocols in molecular biology, 19-10.

406 407

Boo, C. M., Chew, S. Y. J., \& Yong, J. W. H. (2014). Plants in Tropical Cities. Singapore: 1st Edition.

Boratyn, G. M., Camacho, C., Cooper, P. S., Coulouris, G., Fong, A., Ma, N., ... Zaretskaya, I. (2013). BLAST: a more efficient report with usability improvements. Nucleic Acids Research, 41(Web Server issue), W29-W33. http://doi.org/10.1093/nar/gkt282

Boulter, S. L., Kitching, R. L., \& Howlett, B. G. (2006). Family, visitors and the weather: patterns of flowering in tropical rain forests of northern Australia. Journal of Ecology, 94(2), 369-382.

Brandon-Mong, G. J., Gan, H. M., Sing, K. W., Lee, P. S., Lim, P. E., \& Wilson, J. J. (2015). DNA metabarcoding of insects and allies: an evaluation of primers and pipelines. Bulletin of entomological research, 105(6), 717-727.

Bumrungsri, S., Sripaoraya, E., Chongsiri, T., Sridith, K., \& Racey, P. A. (2009). The pollination ecology of durian (Durio zibethinus, Bombacaceae) in southern Thailand. Journal of Tropical Ecology, 25(01), 85-92.

Bumrungsri, S., Lang, D., Harrower, C., Sripaoraya, E., Kitpipit, K., \& Racey, P. A. (2013). The dawn bat, Eonycteris spelaea Dobson (Chiroptera: Pteropodidae) feeds mainly on pollen of economically important food plants in Thailand. Acta Chiropterologica, 15(1), 95-104. doi:10.3161/150811013X667894 
424 CBOL Plant Working Group. (2009). A DNA barcode for land plants. Proceedings of the $425 \quad$ National Academy of Sciences, 106(31), 12794-12797.

426 Chao, A. \& Shen, T.J. (2010). User's Guide for Program SPADE (Species Prediction And 427 Diversity Estimation). Retrieved from http://chao.stat.nthu.edu.tw/wordpress/wp428 content/uploads/software/SPADE_UserGuide(20160621).pdf

429

430

431

432

433

434

435

436

437

438

439

440

441

442

443

444

Chao, A. \& Chiu, C. H. (2016). Species richness: estimation and comparison. Wiley StatsRef: Statistics Reference Online. 1-26. doi: 10.1002/9781118445112.stat03432.pub2

Chen, S., Yao, H., Han, J., Liu, C., Song, J., Shi, L., ... \& Luo, K. (2010). Validation of the ITS2 region as a novel DNA barcode for identifying medicinal plant species. PLoS one, 5(1), e8613.

Chen, Y. Y., Satake, A., Sun, I., Kosugi, Y., Tani, M., Numata, S., ... \& Wright, S. J. (2017). Species-specific flowering cues among general flowering Shorea species at the Pasoh Research Forest, Malaysia. Journal of Ecology, doi: 10.1111/1365-2745.12836

Clare, E. L., Symondson, W. O., Broders, H., Fabianek, F., Fraser, E. E., MacKenzie, A., ... \& Menzies, A. K. (2014). The diet of Myotis lucifugus across Canada: assessing foraging quality and diet variability. Molecular Ecology, 23(15), 3618-3632.

Corbet, S. A., Beament, J., \& Eisikowitch, D. (1982). Are electrostatic forces involved in pollen transfer?. Plant, Cell \& Environment, 5(2), 125-129.

Corlett, R. T. (2005). Interactions between birds, fruit bats and exotic plants in urban Hong Kong, South China. Urban Ecosystems, 8(3), 275-283.

Corner, E. J. H. (1997). Wayside Trees of Malaya. United Selangor Press, Malaysia. pp. 861. 
445 De Barba, M., Miquel, C., Boyer, F., Mercier, C., Rioux, D., Coissac, E., \& Taberlet, P. (2014).

446 DNA metabarcoding multiplexing and validation of data accuracy for diet assessment:

447 application to omnivorous diet. Molecular Ecology Resources, 14(2), 306-323.

448 de Vere, N., Jones, L. E., Gilmore, T., Moscrop, J., Lowe, A., Smith, D., ... \& Ford, C. R. (2017). Using DNA metabarcoding to investigate honey bee foraging reveals limited flower use despite high floral availability. Scientific Reports, 7, 42838.

451

Delaney, J. T., Jokela, K. J., \& Debinski, D. M. (2015). Seasonal succession of pollinator floral resources in four types of grasslands. Ecosphere, 6(11), 1-14.

Faeth, S. H., Warren, P. S., Shochat, E., \& Marussich, W. A. (2005). Trophic dynamics in urban communities. AIBS Bulletin, 55(5), 399-407.

Fleming, T. H., Geiselman, C., \& Kress, W. J. (2009). The evolution of bat pollination: a phylogenetic perspective. Annals of Botany, 104(6), 1017-1043.

Fu, L., Niu, B., Zhu, Z., Wu, S., \& Li, W. (2012). CD-HIT: accelerated for clustering the nextgeneration sequencing data. Bioinformatics, 28(23), 3150-3152.

García-Robledo, C., Erickson, D. L., Staines, C. L., Erwin, T. L., \& Kress, W. J. (2013). Tropical plant-herbivore networks: reconstructing species interactions using DNA barcodes. PLoS One, 8(1), e52967.

Giardine, B., Riemer, C., Hardison, R. C., Burhans, R., Elnitski, L., Shah, P., ... \& Miller, W. (2005). Galaxy: a platform for interactive large-scale genome analysis. Genome research, 15(10), 1451-1455. 
465 Gould, E. (1988). Wing-clapping sounds of Eonycteris spelaea (Pteropodidae) in 466 Malaysia. Journal of Mammalogy, 69(2), 378-379.

467 Grimm, N. B., Faeth, S. H., Golubiewski, N. E., Redman, C. L., Wu, J., Bai, X., \& Briggs, J. M. 468 (2008). Global change and the ecology of cities. Science, 319(5864), 756-760.

469 Grismer, L. L., Onn, C. K., Anuar, S., \& Muin, M. A. (2014). Cyrts in the city: A new Bent-toed 470 Gecko (Genus Cyrtodactylus) is the only endemic species of vertebrate from Batu Caves, 471 Selangor, Peninsular Malaysia. Zootaxa, 3774(4), 381-394.

472 Hebert, P. D., Cywinska, A., \& Ball, S. L. (2003). Biological identifications through DNA 473 barcodes. Proceedings of the Royal Society of London B: Biological Sciences, 270(1512), $474 \quad 313-321$.

475 Herrera, M., Gerardo, L., \& Martínez Del Río, C. (1998). Pollen digestion by New World bats: 476 effects of processing time and feeding habits. Ecology, 79(8), 2828-2838.

477 Horner, M. A., Fleming, T. H., \& Sahey, C. T. (1998). Foraging behaviour and energetics of a 478 nectar-feeding bat, Leptonycteris curasoae (Chiroptera: Phyllostomidae). Journal of $479 \quad$ Zoology, 244(4), 575-586.

480 Hsieh, T.C., Ma, K.H. \& Chao, A. (2016). iNEXT: An R package for rarefaction and 481 extrapolation of species diversity (Hill numbers). Methods in Ecology and Evolution, 482 7(12), 1451-1456. doi:10.1111/2041-210X.12613.

483 Kartzinel, T. R., Chen, P. A., Coverdale, T. C., Erickson, D. L., Kress, W. J., Kuzmina, M. L., ... 484 \& Pringle, R. M. (2015). DNA metabarcoding illuminates dietary niche partitioning by 
African large herbivores. Proceedings of the National Academy of Sciences, 112(26), 8019-8024.

487

488

Kasim, A. (2011). Balancing tourism and religious experience: Understanding devotees' perspectives on Thaipusam in Batu Caves, Selangor, Malaysia. Journal of Hospitality Marketing \& Management, 20(3-4), 441-456.

Kiew, R., Chung, R. C. K., Saw, L. G., \& Soepadmo, E. (2010 - 2015). Flora of Peninsular Malaysia, Series II. Malayan Forest Records No. 49. Seed plants, 5 volumes. Kepong: Forest Research Institute Malaysia.

Kowarik, I. (2011). Novel urban ecosystems, biodiversity, and conservation. Environmental Pollution, 159(8), 1974-1983.

Lim, V. C., Ramli, R., Bhassu, S., \& Wilson, J. J. (2017a). A checklist of the bats of Peninsular Malaysia and progress towards a DNA barcode reference library. PloS One, 12(7), e0179555. doi:10.1371/journal.pone.0179555

Lim, V. C., Clare, E. L., Littlefair, J. E., Ramli, R., Bhassu, S., \& Wilson, J. J. (2017b). Impact of urbanisation and agriculture on the diet of fruit bats. Urban Ecosystem, doi:10.1007/s11252-017-0700-3

Morales, C. L., \& Traveset, A. (2009). A meta-analysis of impacts of alien vs. native plants on pollinator visitation and reproductive success of co-flowering native plants. Ecology Letters, 12(7), 716-728. doi: 10.1111/j.1461-0248.2009.01319.x 
504 Moseley, M. (2009). Estimating diversity and ecological status of cave invertebrates: some 505 lessons and recommendations from Dark Cave (Batu Caves, Malaysia). Cave and Karst $506 \quad$ Science, $35(1), 47-52$.

507 Moseley, M., Lim, T. W., \& Lim, T. T. (2012). Fauna reported from Batu caves, Selangor, 508 Malaysia: annotated checklist and bibliography. Cave and Karst Science, 39(2), 77-92.

509 Nakamoto, A., Kinjo, K., \& Izawa, M. (2007). Food habits of Orii's flying-fox, Pteropus

510 dasymallus inopinatus, in relation to food availability in an urban area of Okinawa-jima

511 Island, the Ryukyu Archipelago, Japan. Acta Chiropterologica, 9(1), 237-249.

512 Nor Zalipah, M., Anuar, S., Sah, M., \& Jones, G. (2016). The potential significance of

513 nectar-feeding bats as pollinators in mangrove habitats of Peninsular Malaysia. Biotropica, $514 \quad 48(4), 425-428$.

515 Oleksy, R., Racey, P. A., \& Jones, G. (2015). High-resolution GPS tracking reveals habitat 516 selection and the potential for long-distance seed dispersal by Madagascan flying foxes 517 Pteropus rufus. Global Ecology and Conservation, 3, 678-692.

518 Parris, B.S., R. Kiew, R.C.K. Chung and L.G. Saw. (2010 - 2013). Ferns and lycophytes. Flora 519 of Peninsular Malaysia, Series I. Malayan Forest Records No. 48. 2 volumes. Kepong: $520 \quad$ Forest Research Institute Malaysia. 243 pp.

521 Phua, P.B. \& Corlett, R.T. (1989). Seed dispersal by the lesser short-nosed fruit bat (Cynopterus 522 brachyotis, Pteropodidae, Megachiroptera). Malayan Nature Journal 42: 251-256. 
523 Pompanon, F., Deagle, B. E., Symondson, W. O., Brown, D. S., Jarman, S. N., \& Taberlet, P.

524 (2012). Who is eating what: diet assessment using next generation sequencing. Molecular $525 \quad$ Ecology, 21(8), 1931-1950.

526 Price, L. (2002). Dark Cave Surveys. Malaysian Naturalist, 55(3), 38-39.

527 Prosser, S. W., \& Hebert, P. D. (2017). Rapid identification of the botanical and entomological 528 sources of honey using DNA metabarcoding. Food Chemistry, 214, 183-191.

529 R Core Team, (2017). R: A language and environment for statistical computing. R Foundation 530 for Statistical Computing. R Foundation for Statistical Computing, Vienna, Austria.

$531 \quad$ http://www.R-project.org/.

532 Ridley, H.N. (1922 - 1925). Flora of Malay Peninsula. 5 volumes. Suffolk: Richard Clay \& 533 Sons, pp. 633.

534 Rognes, T., Mahé, F., \& Xflouris (2015). vsearch: VSEARCH version 1.0.16.

535 doi:10.5281/zenodo. 15524

536

537

538

539
Scanlon, A.T., Petit, S., Tuiwawa, M. \& Naikatini, A. (2014). High similarity between a batserviced plant assemblage and that used by humans. Biological Conservation 174: 111119.

Schneider, A., Mertes, C. M., Tatem, A. J., Tan, B., Sulla-Menashe, D., Graves, S. J., Patel, N. N., Horton, J. A., Gaughan, A. E., Rollo, J. T., Schelly, I. H., Stevens, F. R. \& Dastur, A. (2015). A new urban landscape in East-Southeast Asia, 2000-2010. Environmental Research Letters, 10(3), 034002. doi:10.1088/1748-9326/10/3/034002 
543 Sheherazade, Yasman, Pradana, D. H. \& Tsang, S. M. (2017). The role of fruit bats in plant

544 community changes in an urban forest in Indonesia. Raffles Bulletin of Zoology, 65, 497-

$545 \quad 505$

546 Srithongchuay, T., Bumrungsri, S., \& Sripao-raya, E. (2008). The pollination ecology of the late-

547 successional tree, Oroxylum indicum (Bignoniaceae) in Thailand. Journal of Tropical

$548 \quad$ Ecology, 24(05), 477-484.

549 Start, A. N. (1974). The feeding biology in relation to food sources of nectarivorous bats

550 (Chiroptera: Macroglossinae) in Malaysia (Doctoral dissertation, University of Aberdeen).

551 Start, A. N., \& Marshall, A. G. (1976). Nectarivorous bats as pollinators of trees in West

552 Malaysia. In Tropical trees: variation, breeding and conservation (pp. 141-149). London:

$553 \quad$ Academic Press.

554 Stewart, A. B., \& Dudash, M. R. (2017). Flower-visiting bat species contribute unequally toward

555 agricultural pollination ecosystem services in southern Thailand. Biotropica, 49(2), 239-

556 248. doi:10.1111/btp. 12401

557 Sugita, N., Ootsuki, R., Fujita, T., Murakami, N., \& Ueda, K. (2013). Possible spore dispersal of

558 a bird-Nest fern Asplenium setoi by Bonin flying foxes Pteropus pselaphon. Mammal

$559 \quad$ Study, 38(3), 225-229. doi:10.3106/041.038.0301

560 Tan, K. H., Zubaid, A., \& Kunz, T. H. (1998). Food habits of Cynopterus brachyotis

561 (Muller)(Chiroptera: Pteropodidau) in Peninsular Malaysia. Journal of Tropical

562 Ecology, 14(3), 299-307. 
563 Tan, K. H., Zubaid, A., \& Kunz, T. H. (2000). Fruit dispersal by the lesser dog-faced fruit bat,

564 Cynopterus brachyotis (Müller)(Chiroptera: Pteropodidae). Malayan Nature Journal, $565 \quad 54(1), 57-62$.

566 Thavry, H., Cappelle, J., Bumrungsri, S., Thona, L., \& Furey, N. M. (2017). the diet of the cave 567 nectar bat (Eonycteris spelaea Dobson) suggests it pollinates economically and 568 ecologically significant plants in Southern Cambodia. Zoological Studies, 56(17).

569 Whitmore, T. C. (1972 - 1989). Tree flora of Malaya. A manual for foresters. 4

$570 \quad$ volumes. Malayan Forest Records No. 26. Malaysia: Longman.

571 Win, S.S. \& Mya, K.M. (2015). The diet of the Indian Flying Fox Pteropus giganteus (Brünnich.

572 1782) (Chiroptera: Pteropodidae) in Myanmar - conflicts with local people? Journal of Threatened Taxa 7(9): 7568-7572.

574 Wong, K. M. (1989). Rubiaceae. In Tree Flora of Malaya: a Manual for Foresters Vol 4. (pp. 575 472-478). Malaysia: Longman.

576 
Figure $\mathbf{1}$ (on next page)

A permanent roosting colony of Eonycteris spelaea was located at Dark Cave Conservation Site, one of the caves in Batu Caves.

(a) The location of Dark Cave Conservation Site in Peninsular Malaysia (b) Land cover of Selangor state where Dark Cave is located (source: http://www.globalforestwatch.org/) (c) Close-up of E. spelaea taken by VCL (d) Batu Caves serves as temple for Hindu prayers and tourist attraction for its cultural and natural heritage, photographed by VCL. 
A

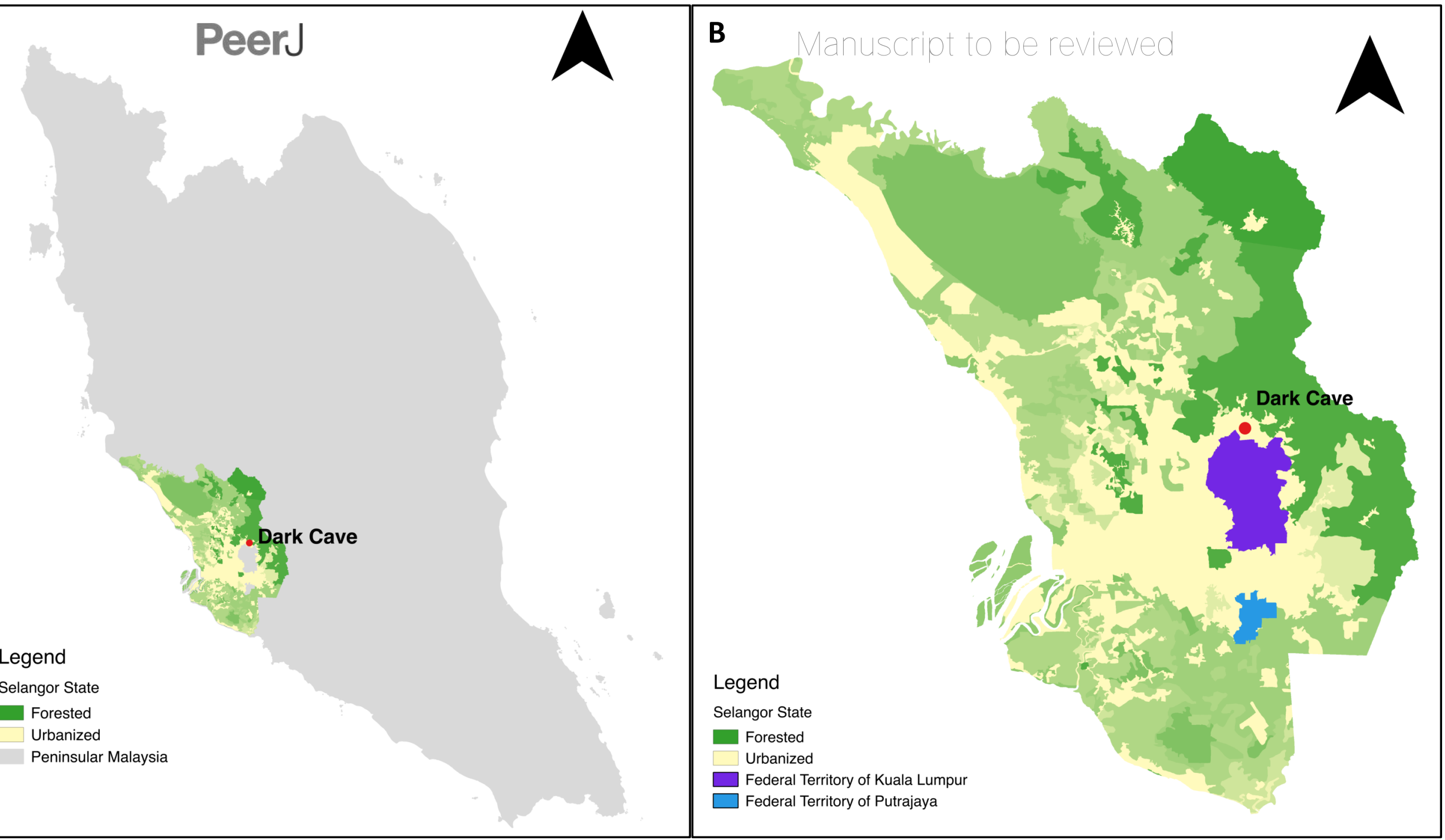

Forested

Federal Territory of Kuala Lumpur

Federal Territory of Putrajaya
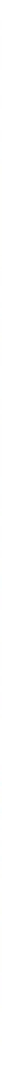
Figure 2 (on next page)

Plant species detected from faecal samples of Eonycteris spelaea using DNA metabarcoding for ten weeks ( $31^{\text {st }}$ of December 2015 to $4^{\text {th }}$ of March 2016).

Order of y-axis is based on (i) number of detection, (ii) taxonomic rank (i.e., species, genus and family), (iii) alphabetical order and (iv) date of detection. 
Artocarpus heterophyll is

Duabanga grandiflora-

Musa balbisiana-

Ceiba pentandra

Musa acuminata-

Urophyllum leucophlaeum-

Dicranopteris sp.-

Oroxylum indicum-

Syzygium samarangense-

Xanthostemon chrysanthus-

Macaranga sp. -

Cyatheaceae -

Musa sp.-

Mangifera indica-

Thelypteridaceae-

Manilkara zapotaArecaceae-

Carica papayaLeucaena leucocephalaSonneratia caseolaris-

Syzygium jambos-

Lejeuneaceae-

Bauhinia strychnoidea-

Beta vulgaris-

Croton argyratus-

Dimocarpus longan-

Ficus calcicola-

Mallotus paniculatus-

Mikania micrantha-

Piper aduncum-

Punica granatum-

Chrysanthemum sp.Citrus sp.

Durio sp.-

Ficus sp. -

Schefflera sp. -

Ficus benjamina-

Bidens pilosa-
Limahlania crenulata-

Lagerstroemia speciosa-
Oldenlandia corymbosa-

Cyathula prostrata-

Artocarpus elasticus-

Diplazium esculentum-

Mimusops elengi-

Cuminum cyminum-

Trema cannabina-

Foeniculum vulgare-

Nephelium ramboutan-ake-

Pyrus sp.-

Etlingera sp.

Eucalyptus sp.

Pleocnemia sp.

Vitex $s p$.

Adiantum sp. -

Dec 31 Jan 8 Jan 15 Jan 22 Jan 29 Feb 5 Feb 12 Feb' 19 Feb 26 Már 4

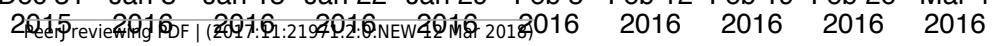

\section{Flowering Phenology}

- flower all year round

only flower during this season

may flower during this season

$\notin$ does not flower during this season

$\oplus$ non-flowering plant

$\bigcirc$ lack of information

\section{Relative Detection Rate in}

\section{Faeces of Cave Nectar Bats}

$\square$ "frequently" detected

"moderately" detected

"infrequently" detected 
Figure 3 (on next page)

Rarefaction and extrapolation sampling curves for this study (from 31st of December 2015 to 4th of March 2016) showing estimated species richness using Chao2.

Sampling curves are extrapolated to one year (52 weeks) with $95 \%$ confidence interval, number of replications $=100$, and sampling completeness ratio $=0.912$. (a) Sample-sizedbased rarefaction and extrapolation curve (b) Sample completeness-based rarefaction and extrapolation curve. 


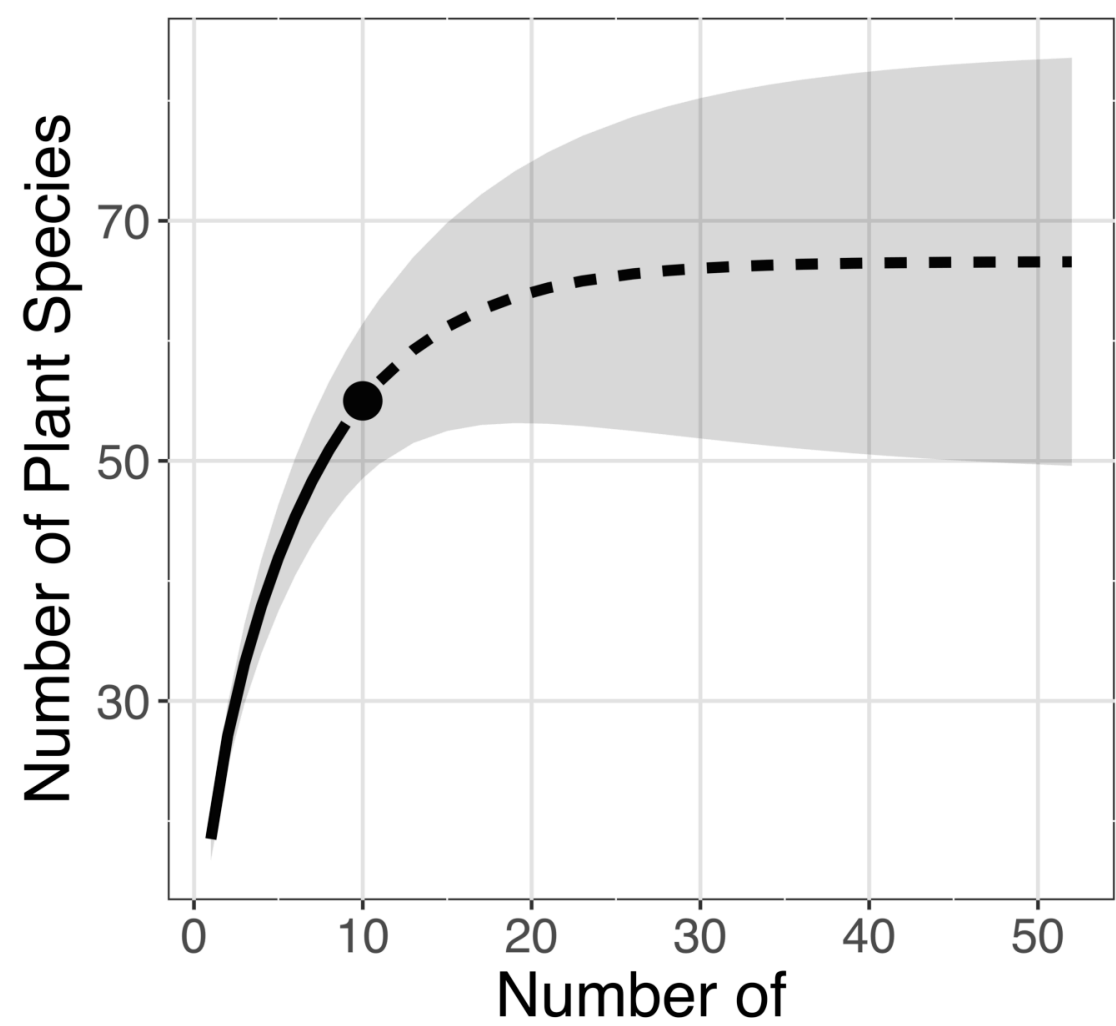

Sampling Weeks

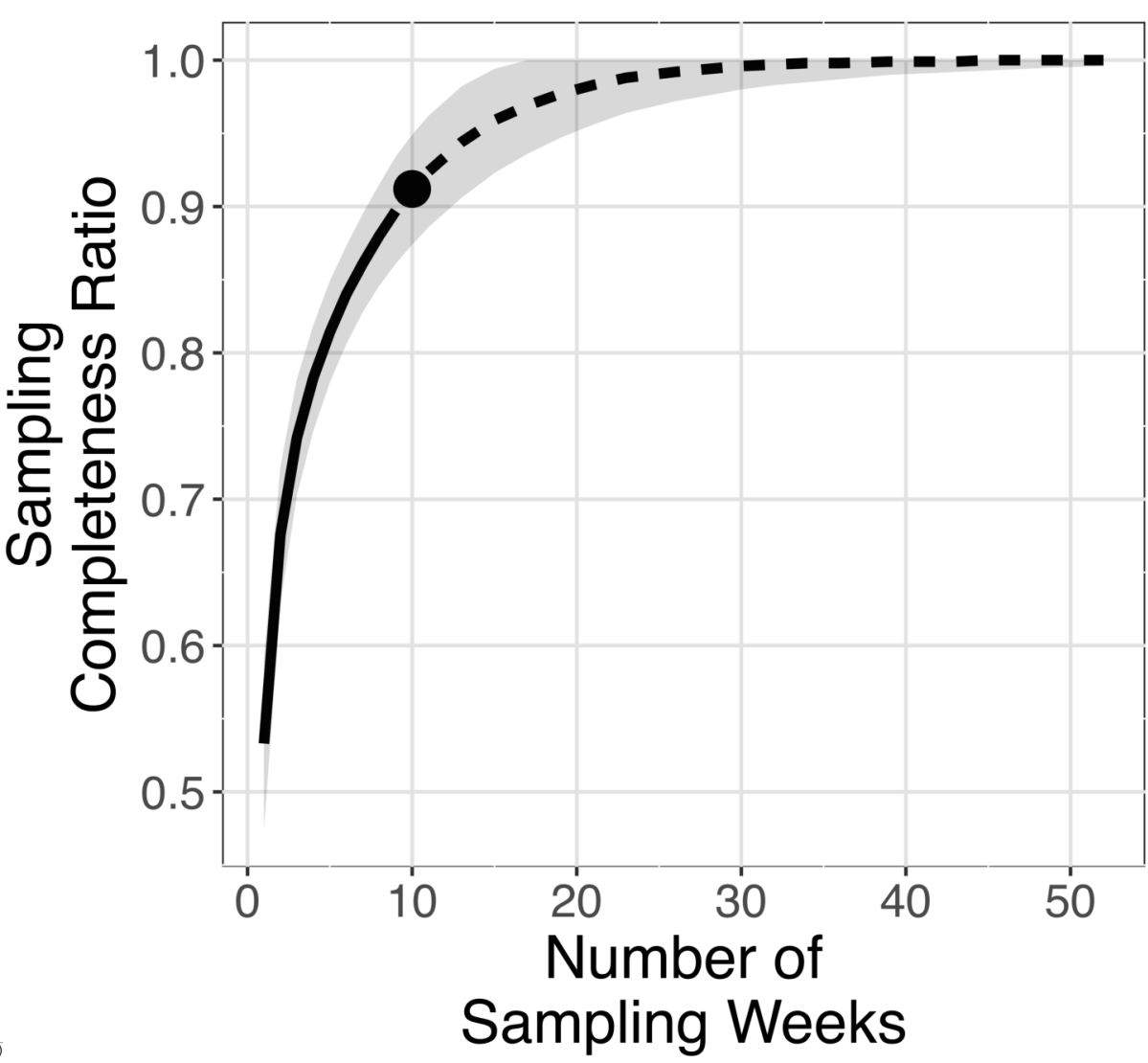




\section{Table $\mathbf{1}$ (on next page)}

Estimated plant richness in the faecal samples of $E$. spelaea of which the number of observed species is 55 , the number of faecal sample is 10 and the total number of incidences is 185 . 
1 TABLE 1. Estimated plant richness in the faecal samples of E. spelaea of which the number of

2 observed species is 55 , the number of faecal sample is 10 and the total number of incidences is 3185.

\begin{tabular}{lllll}
\hline Species & Estimate & Standard & Lower Limit of & Upper Limit of \\
Richness Model & & Error & $\mathbf{9 5 \%}$ & $\mathbf{9 5 \%}$ \\
& & & Confidence & Confidence \\
& & & Interval & Interval \\
\hline Homogenous & 60.324 & 2.996 & 56.904 & 69.882 \\
Model $^{\mathrm{a}}$ & & & & \\
Chao2 $^{\mathrm{b}}$ & & & & 89.766 \\
Chao2-bc $^{\mathrm{c}}$ & 65.260 & 7.040 & 58.873 & 86.286 \\
iChao2 $^{\mathrm{d}}$ & 68.961 & 4.356 & 58.365 & 80.372 \\
\hline
\end{tabular}

5 aThis model assumes that all species have same incidence of detection probabilities

6 bThis approach uses the frequencies of uniques and duplicates to estimate the number of

7 undetected species

$8 \quad{ }^{\mathrm{c}} \mathrm{A}$ bias-corrected form for the Chao2 estimator

9 dImproved Chao2 estimator

10 


\section{Table 2 (on next page)}

Checklist of plants consumed by Eonycteris spelaea between December and March.

References: $1=$ Start (1974) reported fourteen plant species; $2=$ Bumrungsri et al. (2013) reported nine plant species; $3=$ Thavry et al. (2017) reported seven plant species; $4=$ This study detected 55 plant species. 
1 TABLE 2. Checklist of plants consumed by Eonycteris spelaea between December and March.

2 References: 1= Start (1974) reported fourteen plant species; 2= Bumrungsri et al. (2013)

3 reported nine plant species; 3=Thavry et al. (2017) reported seven plant species; 4=This study

4 detected 55 plant species.

\begin{tabular}{|c|c|c|c|c|c|}
\hline Family & Species & Status & $\begin{array}{l}\text { Type of } \\
\text { detection }^{\text {a }}\end{array}$ & $\begin{array}{l}\text { Month(s) } \\
\text { of } \\
\text { detection }^{b}\end{array}$ & References \\
\hline \multirow[t]{2}{*}{ Amaranthaceae } & Beta vulgaris & Introduced & DNA & Dec, Feb & 4 \\
\hline & Cyathula prostrata & Native & DNA & Feb & 4 \\
\hline Anacardiaceae & Mangifera indica & Introduced & DNA & Jan - Mar & 4 \\
\hline \multirow[t]{2}{*}{ Apiaceae } & Cuminum cyminum & Introduced & DNA & Feb & 4 \\
\hline & Foeniculum vulgare & Introduced & DNA & Feb & 4 \\
\hline Araliaceae & Schefflera (Unidentified) & & DNA & Feb - Mar & 4 \\
\hline \multirow[t]{3}{*}{ Arecaceaea } & Cocos nucifera & Native & $\mathrm{P}$ & Dec - Mar & 1,2 \\
\hline & Arenga (Unidentified) & & $\mathrm{P}$ & Jan - Mar & 1,2 \\
\hline & (Unidentified) & & DNA & Jan - Feb & 4 \\
\hline Asteraceae & Bidens pilosa & Native & DNA & Jan & 4 \\
\hline \multirow[t]{2}{*}{ Anacardiaceae } & $\begin{array}{l}\text { Chrysanthemum } \\
\text { (Unidentified) }\end{array}$ & Introduced & DNA & Feb - Mar & 4 \\
\hline & Mikania micrantha & Introduced & DNA & Feb & 4 \\
\hline Bignoniaceae & Oroxylum indicum & Native & $\mathrm{P}, \mathrm{DNA}$ & Dec - Mar & $1,2,3,4$ \\
\hline Cannabaceae & Trema cannabina & Native & DNA & Feb & 4 \\
\hline Caricaceae & Carica papaya & Introduced & DNA & Jan - Feb & 4 \\
\hline Compositae & (Unidentified) & & $\mathrm{P}$ & Dec & 1 \\
\hline \multirow[t]{3}{*}{ Euphorbiaceae } & Croton argyratus & Native & DNA & Feb & 4 \\
\hline & Macaranga (Unidentified) & & DNA & Jan - Mar & 4 \\
\hline & Mallotus paniculatus & Native & DNA & Jan - Feb & 4 \\
\hline
\end{tabular}




\begin{tabular}{|c|c|c|c|c|c|}
\hline \multirow[t]{2}{*}{ Fabaceae } & Bauhinia strychnoidea & Native & DNA & Jan - Feb & 4 \\
\hline & Leucaena leucocephala & Introduced & DNA & Jan - Mar & 4 \\
\hline Gentianaceae & Limahlania crenulata & Native & DNA & Jan & 4 \\
\hline Lamiaceae & Vitex (Unidentified) & & DNA & Feb & 4 \\
\hline Leguminosae & Parkia spp. & & $\mathrm{P}$ & Dec - Mar & $1,2,3$ \\
\hline \multirow[t]{6}{*}{ Lythraceae } & Duabanga grandiflora & Native & $\mathrm{Fl}, \mathrm{P}, \mathrm{DNA}$ & Dec - Mar & 1,4 \\
\hline & Lagerstroemia speciosa & Native & DNA & Jan & 4 \\
\hline & Punica granatum & Introduced & DNA & Feb - Mar & 4 \\
\hline & Sonneratia alba & Native & Fl, P & Dec - Feb & 1 \\
\hline & Sonneratia caseolaris & Native & Fl, P, DNA & Dec - Feb & 1,4 \\
\hline & Sonneratia (Unidentified) & & $\mathrm{P}$ & Dec - Mar & 2,3 \\
\hline \multirow[t]{4}{*}{ Malvaceae } & Bombax anceps & Native & $\mathrm{Fl}, \mathrm{P}$ & $\mathrm{Dec}-\mathrm{Feb}$ & 1,3 \\
\hline & Bombax (Unidentified) & & $\mathrm{P}$ & Feb & 2 \\
\hline & Ceiba pentandra & Introduced & Fl, P, DNA & Dec - Mar & $1,2,3,4$ \\
\hline & Durio spp. & Native & $\mathrm{P}, \mathrm{DNA}$ & Dec - Mar & $1,2,3,4$ \\
\hline \multirow[t]{6}{*}{ Moraceae } & Artocarpus elasticus & Native & DNA & Feb & 4 \\
\hline & Artocarpus heterophyllus & Introduced & DNA & Dec - Mar & 4 \\
\hline & Artocarpus (Unidentified) & & $\mathrm{P}$ & Jan - Mar & 1 \\
\hline & Ficus benjamina & Native & DNA & Dec & 4 \\
\hline & Ficus calcicola & Native & DNA & Feb - Mar & 4 \\
\hline & Ficus (Unidentified) & & DNA & Dec, Feb & 4 \\
\hline \multirow[t]{4}{*}{ Musaceae } & Musa acuminata & Native & Fl, DNA & Dec - Mar & 1,4 \\
\hline & $\begin{array}{l}\text { (previously reported as } \\
\text { malaccensis and truncata) }\end{array}$ & & & & \\
\hline & Musa balbisiana & Native & DNA & Dec - Mar & 4 \\
\hline & Musa (Unidentified) & & $\mathrm{Fl}, \mathrm{P}, \mathrm{DNA}$ & Dec - Mar & $1,2,3,4$ \\
\hline Myrtaceae & Syzygium jambos & Native & DNA & Jan - Feb & 4 \\
\hline
\end{tabular}




\begin{tabular}{|c|c|c|c|c|c|}
\hline & $\begin{array}{l}\text { Syzygium malaccensis } \\
\text { (previously reported as } \\
\text { Eugenia malaccensis) }\end{array}$ & Native & $\mathrm{Fl}$ & Dec - Feb & 1 \\
\hline & Syzygium samarangense & Native & DNA & Jan - Feb & 4 \\
\hline & Syzygium (Unidentified) & & $\mathrm{P}$ & Dec - Mar & 1,2 \\
\hline & Xanthostemon chrysanthus & Introduced & DNA & Jan - Feb & 4 \\
\hline & Eucalyptus (Unidentified) & & $\mathrm{P}, \mathrm{DNA}$ & Feb & 3,4 \\
\hline Piperaceae & Piper aduncum & Introduced & DNA & Dec, Mar & 4 \\
\hline Rosaceae & Pyrus (Unidentified) & & DNA & Dec & 4 \\
\hline \multirow[t]{2}{*}{ Rubiaceae } & Oldenlandia corymbosa & Introduced & DNA & Jan & 4 \\
\hline & Urophyllum leucophlaeum & Native & DNA & Dec - Mar & 4 \\
\hline Rutaceae & Citrus (Unidentified) & & DNA & Dec, Feb & 4 \\
\hline \multirow[t]{2}{*}{ Sapindaceae } & Dimocarpus longan & Native & DNA & Feb & 4 \\
\hline & Nephelium ramboutan-ake & Native & DNA & Feb & 4 \\
\hline \multirow[t]{3}{*}{ Sapotaceae } & Manilkara zapota & Introduced & DNA & Jan - Mar & 4 \\
\hline & Mimusops elengi & Native & DNA & Feb & 4 \\
\hline & (Unidentified) & & $\mathrm{P}$ & Feb - Mar & 1 \\
\hline Zingiberaceae & Etlingera (Unidentified) & & DNA & Jan & 4 \\
\hline Athyriaceae & Diplazium esculentum & Native & DNA & Feb & 4 \\
\hline Pteridaceae & Adiantum (Unidentified) & & DNA & Feb & 4 \\
\hline Dryopteridaceae & Pleocnemia (Unidentified) & & DNA & Feb & 4 \\
\hline Gleicheniaceae & $\begin{array}{l}\text { Dicranopteris } \\
\text { (Unidentified) }\end{array}$ & & DNA & Jan - Mar & 4 \\
\hline Thelypteridaceae & (Unidentified) & & DNA & $\begin{array}{l}\text { Dec, Feb - } \\
\text { Mar }\end{array}$ & 4 \\
\hline Cyatheaceae & (Unidentified) & & DNA & Jan - Feb & 4 \\
\hline Lejeuneaceae & (Unidentified) & & DNA & Jan - Mar & 4 \\
\hline
\end{tabular}


$6 \mathrm{a}=$ Type of detection ( $\mathrm{Fl}=$ sighted on and/or caught near flowers, $\mathrm{P}=$ pollen found in faeces

7 and/or on body, $\mathrm{Fr}=$ caught near fruiting trees, DNA=DNA metabarcoding)

$8 \mathrm{~b}=$ Month of the year $(\mathrm{Jan}=$ January, Feb $=$ February, Mar $=$ March, Dec $=$ December $)$

9

10 